Fikrah: Jurnal Ilmu Aqidah dan Studi Keagamaan

ISSN 2354-6147 EISSN 2476-9649

Tersedia online di: journal.stainkudus.ac.id/index.php/fikrah

DOI: $10.21043 /$ fikrah.v5i2.2510

\title{
Semangat dan Militansi Keislaman Kaum Muda di Ruang Publik
}

\author{
Lukis Alam \\ Sekolah Tinggi Teknologi Nasional Yogyakarta \\ lukisalam@gmail.com
}

\author{
Aminah \\ Sekolah Tinggi Teknologi Nasional Yogyakarta \\ aminah_tugiyo@yahoo.com
}

\begin{abstract}
Penelitian ini muncul berdasarkan dinamika kaum muda (mahasiswa) dalam memperjuangkan aspirasinya menegakkan Islam di ruang publik. Masjid dan kampus menjadi tempat berkumpulnya idealisme dan pemikiran keislaman mereka. Keislaman dan kaum muda sudah menjadi identitas khusus yang bernegoisasi dengan modernitas. Penelitian ini hendak memberikan pandangan mengenai progesivitas kaum muda dalam memahami realita keislaman di ruang publik dengan melihat sejauh mana situasi sosial dan politik di Indonesia pada masa Orde Baru maupun pasca reformasi mempengaruhinya. Selain itu, penelitian ini juga memberikan perspektif mengenai identitas kaum muda yang menggunakan simbol keislaman dalam memperjuangkan idealisme mereka di ruang publik. Yogyakarta digunakan sebagai basis penelitian ini karena semangat keislaman kaum muda demikian meningkat, dan sebagai kota pendidikan Yogyakarta telah memainkan peran dalam mentransformasikan kultur keislaman model baru bagi kaum muda.
\end{abstract}

Kata Kunci: Agama, identitas, ideologi, modernitas, kaum muda 


\begin{abstract}
This study examines the dynamics of university students in fighting for their aspiration to uphold Islam in the public sphere. For their presence, mosque and campuses become their ideological base camp and Islamic thought. Islam and young people have become a special identity that negotiates with modernity. This study aims to provide a critical view on the prolongation of youth in understanding the reality of Islam in the public sphere, affected by the social and political situation in Indonesia during the New Order and post-reform era. In addition, it would provide a perspective on the identity of young people who take Islamic symbols in promoting for their ideation into the public sphere Yogyakarta City is selected as fieldwork location because the progressiveness of youth and Islam is increasing, and as the city of education centre Yogyakarta plays a role in transforming the Islamic culture of a new model for young people.
\end{abstract}

Keywords: Identity, ideology, modernity, religion, youth

\title{
Pendahuluan
}

Diskursus agama dalam konstruksi sosial masih hangat diperbicangkan. Relasinya dengan kekuasaan memberikan perspektif berbeda. Di sisi lain agama dijadikan oleh penguasa sebagai kendaraan dalam mendapatkan kepentingan tertentu. Oleh karena itu, terkadang agama memiliki ruang terbatas apabila direlasikan dengan kekuasaan. Depolitisasi agama yang terjadi di Orde Baru menjadi gambaran bahwa tidak selamanya penguasa menyenangi eksistensi agama. Indonesia sebagai negara yang mayoritas Muslim, aspirasinya tidak selalu diakomodir oleh pemerintah. Justru dalam hal ini, Islam ditarik ke dalam jalur yang tidak sewajarnya, bahkan marginalisasi agama begitu terlihat. Agama harus merefleksikan ajaran-ajarannya melalui nilai-nilai kemanusiaan yang hadir dalam struktur sosial masyarakat. Agama bisa menjadi sumber nilai dan norma di era modern. Peneguhan akan esensi agama itu harus didukung oleh perspektif masyarakat yang terbuka. Masyarakat lebih mudah menyelami ajaran agama bila dalam internalisasinya didukung oleh legal standing dari pihak-pihak yang mendukung hal itu, termasuk pemerintah. Sebagai negara yang mayoritas Muslim, Islam memiliki kepentingan itu, di mana agama senantiasa memberikan pengaruh luar biasa yang diakibatkan oleh situasi sosial, politik yang terjadi saat itu (Hidayat \& Nafis, 2003).

Wajah agama memiliki banyak sisi yang dimanfaatkan Orde Baru untuk mengambil keuntungan terhadap situasi yang terjadi. Di sisi lain masyarakat mengalami 
degradasi perubahan yang tidak bisa terkontrol, apalagi situasi sosial demikian cepat berubah. Fungsi agama dibutuhkan dalam menjembatani perubahan tersebut, dekadensi moral dan etika, serta kemerosotan akhlak dilihat sebagai dampak dari kebijakan-kebijakan pemerintah yang berupaya membangun Indonesia sebagai kekuatan besar di asia tenggara. Dalam kaitan itu, umat Islam mencoba melebur dalam kekuasaan, tetapi tidak diberikan ruang. Sehingga yang terjadi, aspirasi umat Islam tidak tersalurkan dengan baik, agama tidak dijadikan kerangka dalam menjalankan kebijakan pemerintahan, namun malah disingkirkan dari panggung politik.

Adanya fenomena baru di kalangan anak muda yaitu munculnya kegelisahan dalam hal ini mahasiswa yang memiliki semangat ingin mengembalikan Islam ke dalam ruang publik. Di mana Islam tidak lagi menjadi simbol, tetapi bisa diaktualisasikan ke dalam masyarakat. Mereka melihat ketidakadilan, ketimpangan sosial, seolah masyarakat menafikan agama sebagai basis kehidupan mereka. Maka di sinilah keprihatinan itu muncul, Islam harus dikembalikan lagi ke dalam posisi yang sentral, dengan tidak berkonfrontasi dengan pemerintah secara langsung untuk mengindari halhal yang tidak diinginkan. Oleh karena itu, mereka mengupayakan menyelenggarakan gerakan-gerakan nonkonfrontatif dengan menyelenggarakan model dakwah yang diselenggarakan di kampus. Kegiatan tersebut diisi oleh para aktifis Islam yang memulai debutnya di organisasi mahasiswa Islam yang tumbuh ketika Orde Baru. Selanjutnya diteruskan oleh generasi berikutnya hingga saat ini. Mereka mencoba menanamkan nilai-nilai kepatuhan, ketaatan (normatif-subtantif) yang ada dalam Islam. Ajaranajaran doktriner merepresentasikan muatan kebaikan, sehingga bisa meningkatkan kualitas pribadi (Samsudin, 2002, hal. 132-133).

Apa yang mereka lakukan, di sisi lain sebagai mahasiswa dan di lain kesempatan mereka menunjukkan etos keislaman merupakan "ekspresi” (Mahmudin, 2006, hal. 23) untuk semakin mengakrabkan terhadap Islam sebagai pondasi kehidupan. Situasi ini semakin menumbuhkan berkobarnya semangat keislaman di dalam diri mereka. Islam harus ditransformasikan menjadi agama yang mencerahkan, membebaskan manusia dari kesesatan pikir dan hati dalam diri manusia (Rosyad, 1995, hal. 77). Fenomena tersebut merupakan pengungkapan identitas (identity revealed) sebagai seorang muslim, mereka sebagai agen perubahan (agent of change), kiprah mereka memiliki nilai penting 
dalam pemberdayaan masyarakat. Mereposisi gejolak yang ada di masyarakat dengan nilai-nilai Islam dengan mengedepankan cara-cara yang ditempuh orang terdahulu (salafus-shalih), sehingga keberadaan mereka di masyarakat bisa memainkan peranan untuk mendekonstruksi pemahaman yang salah, melalui ajaran Islam. Penelitian ini berupaya untuk memberikan perspektif tentang identitas kaum muda yang menggunakan simbol keislaman dalam memperjuangkan idealisme mereka di ruang publik.

\section{Metode Penelitian}

Jenis penelitian ini adalah penelitian kepustakaan (library research) yaitu serangkaian penelitian yang berkenaan dengan metode pengumpulan data pustaka atau penelitian yang objek penelitianya digali melalui beragam informasi kepustakaan yaitu buku, ensiklopedi, jurnal ilmiah, koran, majalah dan dokumen (Syaodih, 2009). Fokus penelitian kepustakaan adalah menemukan berbagai teori, hukum, dalil, prinsip atau gagasan yang digunakan untuk menganalisis dan memecahkan pertanyaan penelitian yang dirumuskan. Adapun penelitian ini menggunakan analisis deskriptif yakni penguraian secara teratur data yang telah diperoleh kemudian diberikan pemahaman dan penjelasan agar dipahami dengan baik oleh pembaca.

\section{Kaum Muda Era Soeharto dan Pasca Reformasi}

Kaum muda senantiasa memberikan warna tersendiri bagi kemajuan sebuah bangsa. Mereka memiliki peran yang sangat strategis terhadap setiap peristiwa yang terjadi. Sepak terjang kaum muda masa kini tidak bisa dilepaskan dari peran generasi sebelumnya. Dalam kosakata bahasa Indonesia, pemuda atau kaum muda dikenal memiliki beragam terminologi. Istilah young human resources (Hasibuan, 2008, hal. 7) seringkali digunakan untuk menggambarkan fungsi pemuda sebagai sumber pembangunan. Mereka ditempatkan sebagai generasi yang masih memiliki idealisme yang cukup baik dan bisa memberdayakan segala potensi yang dimiliki untuk kemajuan bangsa. Kaum muda sebagai objek pemberdayaan masih memerlukan dukungan untuk menumbuhkan potensi dan kemampuan yang lebih efektif supaya dapat bersikap lebih dewasa dan mandiri dalam mengatasi segala problematika yang menghadang. 
WHO (World Health Organization) mendefinisikan pemuda adalah manusia yang berusia antara 10 hingga 24 tahun. Sedangkan Ensiklopedi Americana mengartikan pemuda sebagai masa transisi anak-anak ke dewasa yang disebut sebagai adolescence (mereka yang berusia 12 -13 tahun hingga 21 -22 tahun). Di lain pihak, ada pula yang melihat batasan pemuda dikategorikan dengan melihat jenjang pendidikan mulai dari Sekolah Menengah Pertama hingga Perguruan Tinggi sampai pada tahap ia mulai bekerja (Hasibuan, 2008). Kajian mengenai kaum muda yang direpresentasikan mahasiswa telah memberikan warna tersendiri, para ilmuwan tertarik membahas mengenai pergerakan kaum muda Indonesia. Mereka telah melihat kiprah kaum muda Indonesia memberikan pengaruh yang signifikan terhadap perkembangan suatu bangsa. Para ilmuwan tersebut seperti karya Takashi Shiraisi (1990) yang menulis An Age in Motion; Popular Radicalism in Java 1912-1926. Ben Anderson (1972) dengan karyanya Java in a Time of Revolution, Occupation and Resistence, 1944-1946 dan terakhir George Mc. T Kahin (2003) yang berjudul Nationalism and Revolution in Indonesia.

Tahun 1908 menjadi tonggak pergerakan nasional dengan terbentuknya Budi Utomo di Batavia (Nordholt, 2008, hal. 99). Organisasi tersebut melatarbelakangi lahirnya organisasi lain seperti Sarekat Islam, Indishe Partij, Perhimpunan Indonesia, Partai Nasional Indonesia, Perhimpunan Bangsa Indonesia, Partai Indonesia Raya (Parindra), Gabungan Politik Indonesia (GAPI). Selain organisasi yang bercorak politik, berkembang pula organisasi massa nonpolitik yang bergerak di bidang sosial, pendidikan, dan budaya. Organisasi massa ini ada yang bercorak agama, nasional dan daerah. Di sisi lain, para peneliti berbeda pendapat dalam melihat pergerakan organisasi di Indonesia. Seperti yang disampaikan Rambe (2008), bahwa Syarikat Islam organisasi pelopor gerakan nasionalis Indonesia sedangkan Budi Utomo masih bersifat "Java Sentris".

Cikal bakal didirikannya Budi Utomo berawal dari keinginan dr. Wahidin Sudirohusodo mendirikan yayasan beasiswa (studiesfonds). Ide awal yayasan ini adalah untuk memajukan pengajaran dan pendidikan para pemuda Indonesia agar dapat melanjutkan pendidikannya ke jenjang yang lebih tinggi. Keinginan dr. Wahidin tersebut disampaikan kepada mahasiswa STOVIA (sekolah dokter pribumi) di Jakarta, sehingga didirikanlah organisasi Budi Utomo sebagai ketua Sutomo. Para anggota yang 
direkrut waktu itu masih terbatas di daerah Jawa dan Madura. Pada kongres yang dilaksanakan pada 5 Oktober 1908, Budi Utomo semakin memantapkan tujuannya dalam bidang pendidikan dan pengajaran, ilmu pengetahuan, sosial dan seni budaya. Sehingga organisasi ini belum terjun dalam bidang politik. Kongres tersebut memilih Raden Tumenggung Tirtokusumo sebagai ketua, ia merupakan Bupati Karanganyar, Jawa Tengah. Sebenarnya dari kongres pertama inilah terlihat mulai tersingkirnya peran mahasiswa (Ilyas, 2004).

Era setelah perang Dunia II berakhir, dengan diserangnya Nagasaki dan Hiroshima oleh Sekutu mengakibatkan Jepang kehilangan arah. Hal ini mengakibatkan terjadinya tidak adanya kekuasaan (vacuum of power) sehingga para pemuda menuntut Soekarno dan Hatta untuk segera memproklamirkan kemerdekaan Indonesia. Pada tanggal 17 Agustus 1945 diperingati sebagai hari kemerdekaan Indonesia, yang oleh Ben Anderson disebut sebagai revolusi pemuda (Anderson, 1972, hal. 34). Pada masa Soekarno berkuasa, para pemuda melihat kesewenang-wenangan, pemerintah cenderung melakukan keditaktoran absolut, dan mengabaikan kepentingan rakyat. Maka pemuda kembali bergerak untuk menyuarakan keadilan, mereka turun ke jalan membantu rakyat yang sedang ditindas. Hal ini yang melatarbelakangi Orde Baru berkuasa, mengambil alih kekuasaan Soekarno (Maxwell, 2005, hal. 152-223). Di jaman peralihan itu, Indonesia diliputi kecemasan luar biasa. Keadaan politik, ekonomi tidak menentu dikarenakan era Soekarno lebih mengakomodir nasionalis dan komunis (Stanley \& Santoso, 2005, hal. 115-120). Pergantian kekuasaan era Soekarno ke Soeharto penuh dengan pergolakan, pada tahun 1966 para pemuda melihat kesempatan yang bagus dengan "menjatuhkan" rezim Orde Lama yang tidak lagi aspiratif terhadap rakyat. Para pemuda bergerak dengan mengatasnamakan rakyat, mayoritas dari mereka adalah mahasiswa yang melihat masa depan Indonesia akan lebih baik lagi jika negara dipimpin oleh penguasa yang pro dengan rakyat. Frustasi yang dirasakan oleh pemuda di masa akhir Orde Lama akhirnya terbayarkan dengan pergantian kekuasaan yang dipimpin Seoharto, sehingga dalam hal ini terjadi cultural conflict (Budiman, 2006, hal. 254-257) secara intens. Di berbagai wilayah mengalami euforia pergantian kekuasaan, selain ibukota Jakarta,Bandung dan Yogyakarta bahkan kota-kota lainnya terjadi hal yang sama. 
Saat Soeharto berkuasa terjadi perubahan elite-sosial yang didominasi oleh kalangan kaum mahasiswa. Bahwa didapatkan fakta ketika Orde Baru berkuasa, militer berubah menjadi otoriterianisme dan depolitisasi partai politik dijadikan sebagai cara melanggengkan kekuasaan. Pada era 1970-an hingga 1980-an, kelas sosial masyarakat Indonesia mengalami kenaikan jumlah yang signifikan, yang oleh pengamat diistilahkan sebagai kelas atau golongan menengah dan civil society (Mahyudin \& Alfan, 2009, hal. 31-33). Adopsi dikotomi kelas yang terjadi di era Orde Baru sesungguhnya sudah diawali dengan sintesa yang sudah dibuat oleh Geertz (1976), yang menyajikan tipikal muslim yang ada di pulau Jawa dengan sebutan santri, abangan, dan priyayi. Menurut analisa Emmerson (2015) menyebutkan dialektika politik yang terjadi di era Orde Baru merupakan hasil pergulatan politik kultural yang dilatarbelakangi dari tradisi kolonial yang memanfaatkan elite untuk mengisi jabatan-jabatan birokrasi. Pengagungan stabilitas politik dan keamanan senantiasa digulirkan oleh Orde Baru (Dhakidae \& Hadiz, 2006, hal. 45), di mana era ini menumbuhkan aspirasi bagi kalangan tertentu terutama kalangan menengah, yang kaum muda menjadi salah satu bagiannya. Sistem multipartai memberikan pengaruh pada perilaku elite, di mana masyarakat dibuat tidak aware terhadap dinamika demokrasi di Indonesia. Seiring reformasi bergulir, berbagai ragam pemikiran dimunculkan untuk menghantam otoriterianisme Orde Baru.

Tumbangnya Orde Baru pada tahun 1998 sudah dapat dilihat dua puluh tahun ke belakang yaitu pada pertengahan tahun 1980-an mahasiswa sudah melihat "ketidakberesan" Soeharto dalam mengemban amanah rakyat. Namun karena dukungan militer yang kuat, niat mahasiswa untuk melengserkan Soeharto tidak terlaksana. Mahasiswa menggulirkan reformasi pada tahun 1998 dengan alasan adanya kepentingan pribadi dan keluarga yang tidak dapat dibedakan serta krisis moneter yang menyebabkan jatuhnya nilai rupiah terhadap dolar sehingga mengakibatkan stabilitas ekonomi dan politik tidak stabil (Suparman, 2012, hal. 98-102). Gerakan mahasiswa yang terjadi sebelum era 1998, mengilhami para ilmuwan sosial membuat berbagai pandangan mengenai pergerakan modern mahasiswa. Di satu sisi pergerakan mahasiswa dilihat sebagai konsensus radikalisme mahasiswa sebagai aktifis, sehingga seringkali dikaitkan dengan wacana moral dan idealisme, keberanian mengambil resiko dan ketajaman intelektual. Di sisi lain pergerakan mahasiswa dapat dilihat sebagai suatu 
fragmentasi dan inkonsistensi, di mana mereka tidak memiliki dukungan dan akses kebijakan, dan terisolasi dalam minoritas elit masyarakat Indonesia. Hal ini dirasakan oleh mahasiswa sebagai diskursus mengenai anak muda pasca 1998 ketika reformasi bergulir. Diskursus anak muda (mahasiswa) memberikan kekuatan yang tidak pernah habis untuk dibahas. Kekuatan mahasiswa yang senantiasa secara simbolik-empirik dibentuk melalui "heroisme" yang bernegoisasi dengan perubahan politik di Indonesia semenjak Orde Baru berkuasa berakibat pada meluasnya jaringan yang didukung oleh media yang terkadang berpihak pada mahasiswa. Oleh karena itu, mahasiswa diposisikan sebagai guardian angel untuk melawan rezim yang otoriter.

Menjadi problem ketika mahasiswa dihadapkan pada legitimasi untuk mendukung rezim tertentu, otoriterisasi yang mulai berganti dengan otoriterisasi lain memberikan peluang untuk saling membenturkan kekuatan mahasiswa dengan kekuatan yang mendukung rezim yang sedang berkuasa. Tentu saja sejarah tidak akan berulang, bahwa ketika opini masyarakat digiring dalam tradisi naratif yang menyesuaikan jaman, seperti yang dikemukakan Heryanto (1996) dampak dari gerakan mahasiswa selalu memberikan narasi wacana yang dapat diadopsi ke dalam struktur masyarakat. Narasi perjuangan (heroisme) yang pernah terjadi di masa lampau selalu mudah diingat masyarakat, sehingga dapat menjadi model bagi siapapun yang mendengarnya. Hal tersebut bersifat empirik karena situasi yang terjadi di masa lampau memberikan pola yang berelasi di era kekinian. Era reformasi sebagai tanda turunnya rezim yang tiga puluh dua tahun berkuasa, dilihat sebagai sebuah perlawanan bagi mahasiswa. Setelah reformasi bergulir, terjadi fenomena yang melanda tidak hanya Indonesia melainkan seluruh dunia. Terkikisnya kharisma Orde Baru memberikan peluang pada rezim setelahnya untuk membentuk jaringan yang lebih kuat, disadari atau tidak hal ini berakibat pada meluasnya legitimizing identities pada struktur ekonomi, politik dan teknologi informasi.

Modal kekuasan yang diusung resim Orde Baru terkonsentrasi pada kooptasi presiden dan militer, sehingga menjadi rezim tunggal (pengontrol) bagi masyarakat. Upaya-upaya depolitisasi agama yang terjadi di masa awal rezim Soeharto berkuasa memberikan trauma yang luar bisa pada sebagian masyarakat, mahasiwa dijauhkan dari keterlibatan sosial serta pemaksaan regulasi yang cukup keras turut menjatuhkan moral 
struktur masyarakat karena digiring untuk mendukung rezim yang berkuasa. Namun, setelah reformasi dengan semakin melemahnya peran militer, hak-hak sipil semakin diakomodir di saat yang sama negara mengalami perubahan aturan politik, ekonomi yang mendorong ketidakstabilan regional dalam negeri.

\section{Deliberalisasi Agama Kaum Muda Pasca Reformasi}

Tumbangnya rezim Orde Baru berakibat pada perubahan tatanan sosial, politik, ekonomi dan sebagainya. Hampir semua lapisan demokrasi terbuka lebar. Hal ini berdampak pada perubahan pola kekuasaan yang semula sentralistik menjadi disentralistik. Model Islam yang tertutup di era Orde Baru memberikan peluang untuk terjadinya moderasi Islam pasca reformasi. Era 2000-an Islam mulai disorot karena menjadi perbincangan seantero dunia seperti tragedi WTC di Amerika pada 11 September 2001 dan tragedi Bom Bali pada 12 Oktober 2002 (Lindholm \& Durham, 2010, hal. 2-3), dengan berbagai peristiwa bom yang umat Islam senantiasa menjadi kambing hitam.

Keterbukaan di era reformasi disebabkan oleh globalisasi dan modernisasi, salah satu hal melatarbelakangi itu adalah perkembangan teknologi informasi dan komunikasi. Walaupun demikian, tidak dipungkiri era 80-an kemudahan akses informasi sudah bisa didapatkan. Hal ini melatarbelakangi persebaran Islam di ruang publik semain gencar. Ketersinggungan rezim Orde Baru dengan Islam tidak terlalu bagus dibanding pasca reformasi, munculnya kelompok-kelompok transnasional yang terpengaruh gerakan dari Timur Tengah seperti Mesir memberikan andil dalam menciptakan berbagai ragam diskursus keberagamaan di Indonesia. Gerakan-gerakan transnasional itu telah memunculkan prinsip-prinsip keagamaan yang membangun loyalitas para pengikutnya secara radikal (al-Rasheed, 2007, hal. 4), bahkan dapat ditafsirkan secara fanatik melampaui batas yang telah diterapkan negara dan bangsa (Tibi, 2008, hal. 7). Keyakinan yang didasarkan pada kelompok turut menyumbang perbedaan pada cara pandang agama bukan lagi secara inklusif melainkan ekslusif (Said, 2013, hal. 265).

Ruang Islam di Indonesia yang diberikan kepada gerakan transnasional salah satunya adalah Hizbut Tahrir (Baran, 2004, hal. 34). Gerakan ini memanfaatkan 
globalisasi yang mendapatkan angin segar dari para pengikutnya yang ada di Indonesia, mayoritas mereka adalah kaum muda (mahasiswa). Menariknya, perekrutan Hizbut Tahrir mengusung topik ummah (K. Ali \& Leaman, 2008, hal. 147-148) dalam hal ini kekhalifahan yang melampaui akar-akar nasionalisme kebangsaan. Animo mahasiswa mengikuti gerakan ini didasarkan pada kemapanan organisasi untuk menangkap berbagai isu dan fenomena yang sedang trend dan populer seperti kemerosotan moral, kenakalan remaja, kapitalisme, neo-liberalisme serta sekulerisme yang tidak akan intens disentuh oleh diskursus keagamaan konvensional (Baran, 2004, hal. 34). Sepertinya Hizbut Tahrir lebih kreatif dalam mengusung tema kemasyarakatan yang ditujukan untuk menarik simpati umat, daripada mengusung topik yang hanya berkutat pada isuisu furu'iyah yang tidak menjual nilai kemaslahatan (Baran, 2004, hal. 11).

Transformasi gerakan Islam kampus yang sudah ada semenjak Orde Baru yang kemudian menjelma semakin menggurita pasca reformasi, yang para alumninya bergabung mendirikan PKS. Kegairahan anak muda dalam beraktifitas merupakan fenomena luar biasa, mereka tentunya memiliki semangat tinggi dalam mempelajari dan mengamalkan Islam. Pada era Orde Baru geliat mahasiswa Islam di kampus dengan pusat aktifitas di Mushala atau di Masjid dianggap sebagai hal yang tabu. Persemaian idealisme mereka semakin ideal dan terciptanya iklim yang mendorong Islam ditampilkan di ruang publik. Intensitas mahasiswa dengan Islam tercipta secara cepat dengan semakin sering mereka mengadakan halaqah atau membentuk grup-grup kajian yang membuat mahasiswa mengalami proses radikalisasi pemahaman di mana mereka menginginkan pemurnian pemahaman pada level nilai maupun praktik. Sementara itu kampus dijadikan pusat pertahanan dan gerakan, sehingga dari tempat inilah digelar pengajian dalam kelompok-kelompok kecil dan dari masjid inilah pula skenario demostrasi menggulingkan Orde Baru pada era reformasi dilakukan.

Bukan hal mudah menjadi bagian gerakan kultural yang dipelopori oleh kaum muda ketika itu, di saat anak muda seusia mereka tergoda untuk pergi ke pusat perbelanjaan, hura-hura ke tempat hiburan maka kalangan anak muda ini seakan membuat gebrakan dengan menentang arus modernisasi. Bagi kaum laki-laki tampilan mereka memelihara jenggot sampai dagu, sedangkan bagi kaum perempuannya menutup semua bagian tubuh yang tersisa hanya telapak tangan dan sebagian wajah. 
Oleh masyarakat, penampilan kaum muda yang demikian dianggap "miring”, ekslusif dan fanatik. Kegiatan-kegiatan yang mereka laksanakan digerakkan melalui mushala maupun masjid, sehingga Orde Baru kesulitan menjangkau mereka. Kaum muda itu menciptakan counter cultural tersendiri dalam bagian struktur masyarakat, kegiatan mereka bisa dilihat tetapi sulit dilacak dan dibuktikan eksistensinya. Pada saat yang sama para orangtua terlihat cemas ketika anak-anak perempuannya mengenakan jilbab yang terkesan ekstrim karena kurang populer dan bisa saja mengancam potensi masa depan anak-anak mereka.

Campur tangan kaum muda dalam hal ini mahasiswa, menurut Huntington dan Nelson (1977, hal. 3) memberikan pengaruh terhadap penciptaan kondisi atau suasana yang semakin dinamis. Hal itu mereka lakukan secara individual atau kolektif dengan cara damai atau dengan kekerasan sehingga dinamisasi yang dilakukan mahasiswa itu tidak hanya kegiatan yang otonom dan murni (autonomous participation), namun lebih kepada kegiatan yang dimobilisasi (mobilized participation). Para muslimah muda tersebut menjadi bagian dari dakwah Islam yang terkadang melakukan partisipasi politik yang dimobilisasi. Pada saat yang sama sering menjadi pihak yang melakukan mobilisasi partisipasi politik atau bahkan pada saat yang sama sering dimobilisasi.

\section{Islamisasi Kampus}

Proses modernisasi Islam yang sebenarnya sudah berlangsung dari abad ke 19 Masehi telah mengubah hubungan Islam dan Barat. Terlebih Indonesia sebagai mayoritas Islam di dunia memiliki posisi penting dalam pergaulan global, kegelisahan sebagian kelompok Islam yang tidak diakomodir kepentingannya merupakan permasalahan yang sering melanda. Mereka berwacana syariat dan negara harus disatukan dalam porsi yang sama, hal itu yang memunculkan Islamisasi di berbagai bidang. Ideologi-ideologi barat yang kental dengan kapitalisme dan sekulerisasi senantiasa dijadikan alasan yang melemahkan otoriterisasi Islam (Burgat, 2003, hal. 4246). Islam diharapkan tampil ke ruang publik dengan cara berbeda yang diharapkan berdinamisasi dengan berbagai bidang. Sejatinya ketika Islam hanya dilihat secara parsial, maka ia hanya sebagai ritus semata tidak sampai pada ajaran yang melembaga dalam kehidupan sehari-hari. Sehingga tokoh-tokoh tersebut memandang untuk 
melakukan restorasi kejayaan masa lampau. Maka revivalisme dan puritanisme merupakan jalan satu-satunya yang harus dilakukan untuk menyaingi modernitas Barat.

Pemahaman mengenai kaum muda dalam mengaspirasikan ketertarikan mereka terhadap pergerakan sosial yang melatarbelakangi aktifitas keislaman di kampus tidak dapat dipisahkan dari dinamika kekuasaan Orde Baru. Penulis ingin menunjukkan bahwa gejolak politik dapat mempengaruhi struktur sosial di mana masyarakat tinggal. Mahasiswa memiliki dimensi tersendiri yang mampu mengubah dirinya dan sosial yang diakibatkan oleh kondisi politik. Sepuluh tahun pertama kebijakan politik Orde Baru telah menempatkan Islam pada posisi yang kurang menguntungkan. Sehingga memunculkan kesan bahwa Islam itu tradisionalis, anti modernisasi, anti pembangunan bahkan sering disebut anti Pancasila. Kesan tersebut membuat umat Islam terkena proses marjinalisasi dalam proses modernisasi dan pembangunan di Indonesia. Kenyataan ini membawa konsekuensi psikologis bahkan menjadi suatu beban bagi sebagian pemimpin Islam Indonesia, karena umat Islam di Indonesia merupakan mayoritas. Beban psikologis ini mendorong mereka bergerak melakukan suatu perubahan agar umat Islam di perhitungkan eksistensinya dalam kehidupan berbangsa dan bernegara sehingga dapat mengubah citra negatif Islam dan umatnya (F. Ali \& Effendi, 1986, hal. 122).

Isu-isu Islamisme kontemporer yang menyebar ke Indonesia mayoritas terinspirasi oleh gagasan dan diskursus reformis Mesir seperti Jamaludin Al-Afghani (1838-1897), Muhammad Abduh (1859-1905) dan Rasid Ridha (1865-1935). Tokoh ini terpengaruh oleh kondisi sosial dan politik di negaranya, gagasan-gagasan mereka diusahakan untuk mendukung modernitas (modernizing Islam). Di sisi lain, Islam menjadi payung modernitas (Islamising modernity) (Rippin, 2005, hal. 6). Menurut Richard Mitcell (1993, hal. xv) bahwa gerakan-gerakan Islamis bertujuan pada sebuah reformasi menyeluruh dunia politik, ekonomi dan sosial di negeri tersebut. Oleh karena itu, corak gerakan Islamisme adalah melahirkan keyakinan terhadap Islam sebagai landasan terhadap segala aspek kehidupan yang bersifat privat sampai ke wilayah publik. 
Hal lain yang patut menjadi perhatian adalah konsepsi Jihad. Hal yang sebenarnya tidak boleh dilupakan adalah muncul dan perkembangan konsepsi jihad yang selama bertahun-tahun mengalami perubahan makna. Jihad yang bermula melakukan upaya secara sungguh-sungguh dalam mengerahkan tenaga, pikiran dan harta untuk "kebangkitan Islam" melalui dakwah, ternyata berubah menjadi lebih artifisial dan fisikal. Inilah transformasi pemaknaan jihad yang saat ini sering terjadi di kalangan masyarakat Islam, terutama para pengikut Wahabi atau kaum Wahabisme, yang identik dengan neo-fundamentalisme atau neo-salafi. Wahabi awalnya memaknai jihad adalah perjuangan menegakkan monoteisme, tetapi belakangan jihad adalah sebuah gerakan perlawanan global tanpa kompromi, dengan siapa saja yang secara ideologi berbeda. Abdul Wahab memberikan apresiasi pada kaum Yahudi dan Kristen, sementara Osamah bin Laden tidak ada kompromi, tidak kerja sama dan tidak dialog yang ada adalah perang melawan kaum Yahudi, Kristen dan Barat secara global (Delong-Bas, n.d., hal. 278).

Konsepsi jihad seperti itu tampaknya terus berkembang sampai di Indonesia saat ini, bahwa jihad identik dengan jalan-jalan kekerasan, seperti meletakkan bom di tempat-tempat umum, mencelakakan orang yang berbeda agama dan ideologi serta teror-teror lainnya. Itulah yang dikritik Fazlur Rahman sebagai bentuk salafi yang sempit, bukan salafi yang mengambil semangat seperti Ibn Taymiyah maupun Abu Hamid al- Ghazali. Al-Ghazali menyatakan bahwa perbuatan manusia tidak yang bersifat zhahir, tampak sebagai kebaikan (jihad), tetapi ada perbuatan-perbuatan yang sifatnya batiniah. Inilah yang sesungguhnya menjadi bagian terpentingdalam iman pada Tuhan. Oleh sebab itu, tugas kita bukanlah hanya menjalankan yang fiqih, dalam teologi (ilmu kalam) atau dalam rasionalitas dan batiniah semata. Tetapi semuanya ada dalam tasawuf. Tasawuf inilah salah satu jalan pembuka menuju kebenaran (Rahman, 2001, hal. 163).

Ruang gerak ormas Islam di era Orde Baru dibatasi, terlebih dengan arah depolitisasi Soeharto terhadap umat Islam begitu gencarnya. Penulis ingin menekankan pengaruh ormas Islam transnasional seperti Hizbut Tahrir dan Ikhwanul Muslimin, yang sebenarnya kedua ormas tersebut memiliki pengaruh luar biasa ketika Orde Baru berkuasa. Ormas tersebut sebagai gerakan Islam baru (New Islamic Movement) yang 
senantiasa dituduh Orde Baru sebagai gerakan inkonstitusional yang menjadi musuh pemerintah, oleh karena itu ormas-ormas seperti itu harus diperangi karena tidak sejalan dengan kebijakan pemerintah (Azra, 1999, hal. 80-83). Oleh penulis ormasormas tersebut atau gerakan Islam yang berhaluan keras diistilahkan sebagai Islam kanan. Di kemudian hari ormas-ormas Islam tersebut memberikan dinamika di dalam umat Islam Indonesia, istilah gerakan Tarbiah disematkan untuk memperhalus gerakan agar tidak terendus oleh Orde Baru. Bagi kalangan tertentu gerakan Tarbiah ini dipengaruhi oleh model gerakan transnasional seperti Ikhwanul Muslimin yang berpusat di Mesir, sehingga aktifis-aktifis gerakan ini senang menyebut dirinya sebagai anak ideologis Ikwanul Muslimin (Rahmat, 2008, hal. 10-12).

Gerakan yang bercirikan puritan cukup dengan nuasa ideologi seperti yang dilakukan Ikhwanul Muslimin yang belakangan diteruskan Sayyid Qutb berakibat pada praktek neofundamentalis-salafi cocok diaktulisasikan di Indonesia ketimbang menggunakan jalan kekerasan dan revolusioner seperti yang dilakukan Hasan al-Banna (Fealy, 2005, hal. 11-13). Suasana teologis di masa 1970-an hingga 1980-an terasa membakar semangat Islam di masa itu, terlebih Orde Baru melakukan NKK (Normalisasi Kehidupan Kampus) membuat mahasiswa dibatasi geraknya, kecenderungan mahasiswa Islam mengembangkan religiusitas dengan membentuk gerakan islan yang tidak konfrontatif dengan memilih jalur dakwah yang lebih kultural. Mereka mengambil jalan dakwah melalui kampus, dakwah kampus mengambil gerakan non-konfrontatif, gerakan tidak formal bahkan tidak terlembaga, tetapi terhubung oleh jejaring informal dengan sesama partisipan. Hal inilah yang dinamakan dengan konsep struktur organisasi rahasia dan dakwak terbuka (Muhtadi, 2012, hal. 104).

Hal lain yang dilakukan mahasiswa Islam menyikapi kebijakan Orde Baru yang represif adalah dengan pengkaderan di kalangan mereka sendiri. Ada yang menyebut dengan LKD (latihan kader dakwah), LMD (latihan mujahid dakwah) dan SII (studi Islam intensif). Hal ini semata-mata dilakukan sebagai langkah untuk memperkuat posisi gerakan dakwah kampus dalam bernegoisasi dengan suasana politik di masa itu (Asshiddiqie, 2002, hal. 257). Tahun 1980-an merupakan bagian penting dari perkembangan Islam di Indonesia. Pada tahun 1980-an ini, di kampus-kampus tidak berbasis keislaman seperti Institut Teknologi (ITB), Institut Pertanian Bogor (IPB), 
Universitas Indonesia (UI) dan Universitas Brawijaya berkembang kelompok-kelompok pengajian kampus, yang sering disebut sebagai Gerakan Dakwah Kampus, jamaah musholla, usrah-usrah, kelompok tarbiah dan halaqah (Qodir, 2008).

Kelompok-kelompok gerakan Islam Kampus ini sekurang-kurangnya mempunyai ciri-ciri, memanjangkan jenggot (yang dianggap sebagai bagian dari sunah Nabi), memanjangkan jilbab, yang sebelumnya pemakaian jilbab hanyalah identik dengan krudung (kerudung Mbak Tutut/Ibu Shinta Abdurrahman Wahid), belakangan berkembang menjadi jilbab Astri Ivo, Inneke Koesherawati, Desy Ratnasari, Ratih Sanggarwati, bahkan sebelumnya jilbab dan mukena Krisdayanti bagi kelompok jamaah pengajian kampus yang perempuan. Sementara untuk kelompok laki-lakinya, selain memanjangkan jenggot, memakai pakaian congklang dan baju gamis (kita bilang baju koko), menghitamkan jidad, dan memanggilnya dengan sebutan "ana" untuk saya dan "antum" untuk anda atau kamu. Dua kosa kata ini hampir senantiasa dipakai oleh kelompok jamaah pengajian kampus sehingga membedakan dengan kelompok jamaah lainnya. Bahkan ada yang menyebutnya dengan panggilan "ikhwan" dan "akhwat", identifikasi pada Ikhwanul Muslimin (Qodir, 2008).

Kelahiran Gerakan Tarbiah di Indonesia tidak lepas dari gerakan dakwah kampus. Dua hal penting yang dapat dijadikan pijakan dalam mengidentifikasi kelahiran gerakan dakwah kampus. Pertama, berkenaan dengan munculnya kelompok muda yang bersemangat tinggi mempelajari dan mengamalkan Islam sebagai respon atas tekanan politik yang dilakukan Orde Baru terhadap umat Islam. Kedua, adanya ruang publik yang relatif lapang, seperti masjid atau mushola kampus, sebagai tempat idealisme kaum muda Islam mengalami persemaian secara ideal dan cepat (Damanik, 2002, hal. 63). Latihan Kader Dakwah, Latihan Mujahid Dakwah (LMD), dan Studi Islam Intensif (SII) merupakan tonggak penting kelahiran gerakan dakwah kampus. Prinsip yang diajarkan dalam LKD/LMD/SII adalah mengajarkan totalitas pandangan keislaman yang tidak memisahkan antara yang sakral dan sekuler serta yang transendental dan yang temporal. Tokoh yang mempelopori lahirnya dakwah kampus di masa itu salah satunya Imaduddin Abdulrahim, pandangannya yang holistik dan cenderung puritan mengajak para mahasiswa yangdikadernya mewujudkan Islam yang nyata dalam kehidupan (Asshiddiqie, 2002) 
Materi yang diberikan dalam LKD, LMD, dan SII menjadi dasar dalam kajian di masjid-masjid kampus. Kajian dilakukan dalam kelompok kelompok-kecil yang kemudian dikenal dengan sebutan usrah. Kelompok usrah terdiri dari 5-20 orang yang dipimpin oleh seorang ustaz atau mentor yang biasanya mahasiswa senior. Pembentukan kelompok studi keagamaan tersebut menjadi suatu pilihan yang paling realistik bagi aktivis gerakan kampus kala itu. Kajian keagamaan semacam itu, oleh birokrat kampus tampaknya diabaikan dan kurang diwaspadai oleh pihak birokrasi kampus. Sehingga yang terjadi perlahan namun pasti, kelompok kajian keagamaan ini semakin lama semakin membesar. Kelompok ini berhasil memanfaatkan kelengahan birokrat kampus dalam mengendalikan kegiatan politik mahasiswa di kampus (Hwang, 2011, hal. 81-83).

Kegiatan dakwah kampus mencoba membuat regulasi sendiri yang berimbas pada implikasi sosial dan politik yang membuat kecurigaan pemerintah semakin tinggi. Para aktifis itu menginginkan diberlakukannya kesalehan atau nilai-nilai Islami di masyarakat bahkan ingin mengontrol dan mendisiplikan masyarakat terkait sikap dan perilaku rezim. Hal inilah yang melatarbelakangi timbulnya berbagai dakwah kampus di Indonesia. Masing-masing dari mereka memiliki pengalaman keberagamaan berbeda satu dengan lainnya, menurut Ammerman (2007) hal itu sebagai lived-religion itu pengalaman aktual orang beragama yang dilembagakan. Setiap orang memiliki praktik keberagamaan masing-masing (McGuire, 2008, hal. 10-13), sesuai dengan kondisi sosial dan politik mereka berada. Sehingga dengan pengalaman berbeda akan mentransformasikan identitas spritualitas melalui perwujudan kesalehan dan disiplin agama dalam kehidupan sehari-hari.

\section{Dakwah Kampus dan Islam Puritan}

Kegiatan dakwah yang diselenggarakan di era 1980-an oleh mahasiswa Islam merupakan bentuk perlawanan yang nonkonfrontatif terhadap rezim Orde Baru. Hal ini bagian dari ideologi penyebaran Islam di kalangan muda yang tidak mudah diketahui pemerintah Orde Baru. Sebagaimana yang sudah dipaparkan di atas, pengaruh dakwah kampus tidak lepas dari penyebaran ideologi Ikhwanul Muslimin di Indonesia, dengan terbentuknya jamaah tarbiah yang melembaga di berbagai kampus di Indonesia 
memunculkan embrio dakwah yang diorganisir di level kampus. Persinggungan ideologi Ikhwanul Muslimin mulai mempengaruhi pemikiran mahasiswa Islam tatkala Masjid Salman ITB menjadi pioner dakwah kampus di Indonesia. Model pembinaan dengan menggunakan sistem usrah dan konsep Islam kaffah memiliki kesamaan konsep dengan yang digunakan jamaah tarbiah milik Ikwanul Muslimin di Mesir. Masjid Salman mengadopsi konsep usrah setelah sebelumnya terjadi interaksi pemikiran dengan pemikiran gerakan Ikwanul Muslimin melalui buku-buku yang ditulis para pemimpinnnya (Sidiq, 2003, hal. 78).

Pada awalnya dakwah kampus masjid Salman menggunakan buku panduan yang diterbitkan dari Malaysia (Damanik, 2002). Usrah merupakan sistem dakwah Ikhwanul Muslimin berupa kelompok yang terdiri dari lima hinga sepuluh orang yang dipimpin oleh seorang naqib. Sistem ini dibuat Ikhwanul Muslimin berdasarkan SK Muktamar Umum Ikhawanul Muslimin tahun 1943, dalam rangka memenuhi kebutuhan akan sistem yang tetap mampu mewujudkan imtidad ufuqy (perkembangan horisontal) dan nuwuw tarbawy (perkembangan edukatif) para anggota meskipun dalam situasi penuh tekanan politik (Ruslan, 2000, hal. 563). Indikasi lain adanya pengaruh dari gerakan Islam internasional bisa dilihat dari konsepsi pemikiran kaffah yang diusung oleh tokoh-tokoh gerakan dakwah Salman dan sejumlah tokoh LDK lainnya. Imaduddin Abdurrahim misalnya, mengajukan konsep pemahaman Islam Kaffah, yaitu wujud pemahaman ajaran Islam yang menyeluruh, menjangkau semua aspek dan dimensi kehidupan tanpa ada pemilihan satu dengan lainnya. Adanya pandangan yang menyatakan bahwa Islam tidak bisa dilepaskan dari politik dan menjadi sarana memajukan Islam tidak sepenuhnya diterima oleh tokoh semacam Nurcholish Madjid, yang menyerukan pemisahan antara Islam dan politik melalui jargon, "Islam Yes”, Partai Islam No" (Sidiq, 2003).

Pada fase ini, buku-buku terjemahan karya Hasan al-Banna, Sayyid Quthb, dan tokoh lain yang diterbitkan di Malaysia dibawa oleh Imaduddin ke Indonesia dan menjadi buku acuan dalam gerakan dakwah kampus. Kian lama, pemikiran-pemikiran Ikhwanul Muslimin merasuk dan mempengaruhi pemikiran kader dakwah kampus. Selanjutnya dakwah kampus dikenal dengan Lembaga Dakwah Kampus (LDK) memposisikan dan mempromosikan ideologi Ikhwanul Muslimin sebagai dasar dakwah 
mereka. Beberapa prinsip pemikiran Ikhwanul Muslimin yang disosialisasikan dalam LDK diantaranya: Islam merupakan ajaran yang sempurna, tidak memisahkan satu aspek dengan aspek lainnya. Konsepsi Islam yang profan, transenden, sakral serta temporal tidak bisa dilepaskan (Dahlan, 1997). Oleh karena itu konsep yang seperti ini dipahami sebagai Islam kaffah, yaitu wujud pemahaman Islam yang menyeluruh, menjangkau semua aspek dan dimensi kehidupan duniawi-ukhrawi, jasmani maupun ruhani,ubudiyah-mu'amalah, sosial dan politik dengan jargon Al-Islam din wa-Daulah (Sidiq, 2003).

Terbatasnya ruang dalam mewacanakan diskursus keislaman dan politik di ruang publik yang bisa dinikmati masyarakat tampaknya hanya menjadi isapan jempol semata. Hal ini menimbulkan semangat bagi kalangan pemikir dan aktivis Islam mencari alternatif yang memungkinkan. Langkah diversifikasi Islam bukan satu-satunya cara dalam mengembangkan diskursus keislaman dan politik. Namun dengan memperluas jangkauan dalam mengkaji Islam dalam spektrum yang lebih luas maka untuk menjembatani persoalan ini, kampus, masjid dan forum-forum studi menjadi pilihan yang strategis. Karena dari tempat-tempat seperti itu kajian demi kajian dapat dilakukan. Tidak hanya berfungsi untuk menambah pengetahuan mengenai Islam, namun yang lebih penting adalah pendalaman aqidah dan praktik keagamaan yang empirik. Outputnya adalah bagaimana Islam menjadi buku yang paling otoritatif di negeri ini. Oleh karena itu, dengan leluasa siapapun bisa mengkaji dan membacanya. Selain Imaduddin Abdurrahim di masjid Salman ITB, aktivis lainnya yang berjasa terhadap perkembangan dakwah kampus diantaranya: Saefullah Mahyudin, Amien Rais, Kuntowijoyo, Syahirul Alim walaupun tidak setenar Imaduddin, mereka memiliki kontribusi luar biasa terhadap perjuangan dakwah kampus di UGM yang dilakukan melalui masjid Mardhiyah, Masjid Sudirman, Masjid Syuhada, dan Jamaah Shalahuddin. Hal sama juga dilakukan oleh Sholeh Iskandar dan Ahmad Muflih Saefuddin di IPB, di lingkungan jamaah Masjid Al-Ghifari. Demikian juga di lingkungan kampus Universitas Airlangga yang diinisiasi oleh Fuad Amsyari serta Halide di Universitas Hasanuddin (Damanik, 2002).

Era 1980-an hingga 1990-an muncul varian dakwah kampus yang lebih modern. Hal ini membuktikan bahwa dakwah kampus tidak selalu identik dengan politik, 
walaupun pada awalnya kental dengan ideologi Ikhwanul Muslimn, namun aktivitas dakwah kampus era tersebut lebih memilih untuk berkonsentrasi pada hal-hal yang berkaitan dengan Islam yang non-politik. Ketika dakwah ditujukan untuk pembangunan moral manusia, khususnya di kampus maka sejatinya para aktivis dakwah kampus itu telah melakukan pembinaan kehidupan Islam tekstual yang konkrit, kampus tidak hanya menjadi tempat transfer of knowledge tetapi kampus memfokuskan sebagai pembinaan moral intelektual. Oleh karena itu area dakwah pun meluas tidak hanya dalam ruang kelas, melainkan juga telah menyebar ke lembaga-lembaga kegiatan kampus (Setiawan \& Soetapa, 2010, hal. 169).

Perkembangan geopolitik Timur Tengah memang tidak bisa dilepaskan dari Indonesia, perspektif berbeda diberikan oleh Noorhaidi Hasan (2012) mengenai perkembangan dakwah kampus yang melebarkan sayapnya hingga ke beberapa kampus di Indonesia termasuk Yogyakarta. Menurutnya revolusi Iran 1979 memberikan pengaruh pada generasi muda untuk melakukan perubahan terhadap kondisi Indonesia saat itu. Efek modernisasi dan sekularisasi telah merubah situasi dan kondisi masyarakat. Solusi yang ditawarkan terhadap berbagai problematika adalah dengan kembali pada ajaran Islam. Yang dilakukan generasi muda saat itu adalah mengaktualisasikan Islam ke ruang publik seperti penyebaran buku-buku keislaman, penerjemahan karya-karya Ayatullah Khomeini, Murtada Mutahhari, Ali Shariati demikian juga Hassan al-Banna, Sayyid Quthb, Abul A'la al-Maududi dan Mustafa asSiba'i.

Pergulatan pemikiran di kalangan kaum muda terhadap nalar keislaman memberikan sumbangan kebangkitan berpikir secara kritis terhadap aktualisasi Islam lingkungan mereka. Pemikiran-pemikiran transnasional yang telah berkembang di sekeliling mereka, baik yang bersumber dari Nabi Muhammad SAW maupun para generasi Salaf al-Salih (early Muslim generation). Di mana Islam telah terlabel dengan ajaran yang kaffah, yang meliputi segala aspek seperti: sosial, politik, kebudayaan, ekonomi menjadikan Islam diklaim sebagai satu-satunya cara dalam pemenuhan kebutuhan manusia yang berwujud material, spiritual maupun individual. Oleh karena itu dakwah kampus menjadi katalisator penyebaran nilai-nilai Islam (Hasan, 2012, hal. 187). 
Dakwah kampus merupakan pengejawantahan nilai-nilai pendidikan sebagai salah satu kebutuhan dasar dalam hidup, memiliki peranan penting dalam membentuk sikap dan perilaku seseorang. Terwujudnya sikap dan perilaku yang baik dari setiap individu merupakan tujuan utama dari sebuah pendidikan. Hal ini sesuai dengan fungsi dan tujuan pendidikan nasional Indonesia dalam Undang-Undang Sistem Pendidikan Nasional (Sisdiknas) Republik Indonesia bahwa fungsi pendidikan nasional adalah untuk mengembangkan kemampuan dan membentuk watak serta peradaban bangsa yang bermartabat dan tujuannya adalah untuk mengembangkan potensi anak didik agar menjadi manusia yang beriman dan bertakwa kepada Tuhan Yang Maha Esa, berakhlak mulia, sehat, berilmu, cakap, kreatif, mandiri, dan menjadi warga Negara yang demokratis dan bertanggung Jawab.

Undang-undang tersebut mengarahkan peningkatan intensitas kualitas pelaksanaan pendidikan,terutama pendidikan nilai pada sebuah lembaga pendidikan. Pendidikan nilai adalah pendidikan yang mensosialisasikan dan menginternalisasikan nilai-nilai dalam diri sesorang. Penanaman dan pengembangan nilai tersebut merupakan suatu dimensi dari seluruh usaha pendidikan yang tidak hanya terfokus pada pengembangan ilmu, keterampilan, teknologi, tetapi juga pengembangan aspekaspek lainnya, seperti kepribadian, etik-moral, akhlak dan yang lain (Maksudin, 2009, hal. 18). Dalam pendidikan formal pengembangan akhlak mulia dan religius yang mengajarkan pendidikan nilai tentu saja menempati salah satu tugas dari suatu lembaga (Tilaar \& Nugroho, 2008, hal. 30). Lembaga pendidikan formal sebagai wadah resmi pembinaan generasi muda diharapkan dapat meningkatkan peranannya dalam pembentukan kepribadian peserta didik melalui peningkatan intensitas dan kualitas pendidikan.

Dakwah kampus adalah implementasi dakwah ilallah dengan lingkup perguruan tinggi yang dimaksudkan untuk menyeru sivitas akademika ke jalan Islam. Dakwah kampus bergerak di lingkungan masyarakat ilmiah mengedepankan intelektualitas dan profesionalitas. Tujuan dakwah kampus adalah membentuk civitas akademika yang bercirikan intelektualitas dan profesionalitas, memiliki komitmen yang kokoh terhadap Islam, dan mengoptimalkan peran kampus dalam upaya mencapai kebangkitan Islam (Atian, 2010, hal. 25). Kehadiran dakwah kampus sebagai solusi pengalihan terhadap 
kaum muda dari berbagai kondisi sosial yang memprihatinkan, salah satu aspek yang bisa membuat masyarakat tertekan adalah faktor ekonomi yang tidak menentu. Ketimpangan tersebut berpengaruh terhadap pola pikir masyarakat, kalangan kaum muda juga bisa merasakan akibatnya. Mobilitas mereka bisa tersalurkan dengan baik karena terkondisikan dengan frustasi diakibatkan situasi yang tidak menentu. Hal ini akan memberikan dampak kerusakan yang masif terhadap kaum muda. Maka dakwah kampus bisa menjadi alternatif membantu negara memecahkan ketimpangan tersebut.

\section{Simpulan}

Kaum muda yang masih memiliki idealisme dan semangat luar bisa memberikan pengaruh yang demikian besar terhadap setiap fenomena yang terjadi dalam struktur sosial di mana mereka berada. Mereka hidup dalam jaman yang berbeda dan memiliki karakteristik masing-masing. Kebimbangan akan nasib sosial senantiasa dalam pikiran mereka, tidak melupakan hakikat akan menuntut ilmu di jenjang yang lebih tinggi. Di setiap jaman, mereka dipimpin oleh rezim yang berbeda kebijakan. Di mana Indonesia merupakan mayoritas muslim terbesar di dunia, kaum muda ini ingin memperjuangkan status mereka sebagai identitas khusus yang memperjuangkan nilai dan keluhuran melalui agama yang mereka yakini kebenarannnya. Kaum muda (mahasiswa) Islam senantiasa ingin menampilkan identitas ke ruang publik. Semakin berkembangnya jaman, kaum muda itu menciptakan ruang tersendiri yang jauh dari urusan politik dan kekuasaan yang menciptakan identitas mereka sebagai mahasiswa Islam. Sementara itu lahirnya gerakan dakwah kampus menjadi sarana aktualisasi nonkonfrontatif untuk membina kesadaran beragama yang lebih intens di kampus atau universitas. Hal ini menjadi cerminan perlawanan kaum muda terhadap otoritarianisme terhadap kebebasan menjalankan keberagamaan di kampus. 


\section{Referensi}

Al Rasheed, M. (2007). Contesting The Saudi State: Islamic Voice From a New Generation. New York: Cambridge University Press.

Ali, F., \& Effendi, B. (1986). Merambah Jalan Baru Islam. Bandung: Mizan.

Ali, K., \& Leaman, O. (2008). Islam: Key Concepts. London \& New York: Routledge.

Ammerman, N. T. (2007). Everyday religion : observing modern religious lives. Oxford University Press.

Anderson, B. R. O. (1972). Java in a Time Of Revolution: Occupation and Resistance. Ithaca: Cornell Universit Press.

Asshiddiqie, J. (2002). Bang 'Imad: Pemikiran dan Gerakan Dakwahnya. Jakarta: Gema Insani Press.

Atian, A. (2010). Menuju Kemenangan Dakwah Kampus. Solo: Era Intermedia.

Azra, A. (1999). Islam Reformis: Dinamika Intelektual Gerakan. Jakarta: Rajawali Press.

Baran, Z. (2994). Hizbut Tahrir: Islam's Political Insurgency. Washington: The Nixon Center.

Budiman, A. (2006). Kebebasan, Negara, Pembangunan. Jakarta: AlvaBet.

Burgat, F. (2003). Face to Face With Political Islam. London: I.B.Tauris.

Dahlan, A. A. (1997). Ensiklopedi Hukum Islam. Jakarta: PT Ichtiar Baru Van Hoeve.

Damanik, S. Al. (2002). Fenomena Partai Keadilan. Jakarta: Noura.

Delong-Bas, N. J. (n.d.). Wahabi Islam: From Revival and REform to Global Jihad. London: Oxford University Press.

Dhakidae, D., \& Hadiz, V. R. (2006). Ilmu Sosial dan Kekuasaan Indonesia. JakartaSingapura: Equinox Publishing.

Emmerson, D. K. (2015). Indonesia Beyond Suharto. Taylor \& Francis.

Fealy, G. (2005). Jejak Kafilah: Pengaruh Radikalisme Timur Tengah di Indonesia. Bandung: Mizan.

Geertz, C. (1976). The Religion of Java. University of Chicago Press.

Hasan, N. (2012). Islam politik di dunia kontemporer: konsep, genealogi, dan teori. SukaPress. 
Hasibuan, M. (2008). Revolusi Politik Kaum Muda. Jakarta: Yayasan Obor.

Heryanto, A. (1996). Indonesian Muddle-class Opposition in the 1990s. In G. Rodan (Ed.), Political Oppositions in Industrialising Asia. Psychology Press.

Hidayat, K., \& Nafis, M. . (2003). Agama Masa Depan: Perspektif Filsafat Perenial. Jakarta: Gramedia.

Huntington, S. P., \& Nelson, J. M. (1977). No Easy Choice: Political Participation in Developing Countries. Harvard: Harvard University Press.

Hwang, J. C. (2011). Umat Bergerak: Mobilisasi Damai Kaum Islamis di Indonesia, Malaysia dan Turki. Jakarta: Freedom Institute.

Ilyas, H. (2004). Akar Fundamentalis dalam Perspektif Tafsir AL-Quran. In A. M. Abegebriel \& A. Y. A. Abeveiro (Ed.), Negara Tuhan The Thematic Encyclopdeia. Yogyakarta: Multi Karya Grafika.

Kahin, G. M. T. (2003). Nationalism and Revolution in Indonesia. Southeast Asia Program Publications, Southeast Asia Program, Cornell University.

Lindholm, T., \& Durham, W. C. (2010). Kebebasan Beragama atau Berkeyakinan: Seberapa Jauh? Yogyakarta: Kanisius.

Mahmudin, N. (2006). Islamising Indonesia: The Rise of Jamaah Tarbiyah and Prosperous Justice Party. Australia: Australian National University Press.

Mahyudin, A., \& Alfan, M. (2009). Menjadi Politik. Jakarta: Gramedia.

Maksudin. (2009). Pendidikan Nilai Komprehensif: Teori dan Praktek. Yogyakarta: Press.

Maxwell, J. (2005). Soe Hok Gien Intelektual Muda MElawan Tirani: Pergulata. Jakarta: Pustaka Utama Grafiti.

McGuire. (2008). Lived Religion: Faith and Practice in Every day Life. Oxford: Oxford Univeristy Press.

Mitchell. (1993). The Society of The Muslim Brothers. Oxford: Oxford University Press.

Muhtadi, B. (2012). Dilema PKS: Suara Syariah. Jakarta: Gramedia.

Nordholt, H. S. (2008). Penulisan Sejarah Indonesia. Jakarta: Obor.

Qodir, Z. (2008). Gerakan Islam Politik Kontemporer di Indonesia. Diskusi Serial Terbatas Islam, HAM dan Gerakan Sosial di Indonesia. 
Rahman, F. (2001). Kebangkitan dan Pembaharuan di Dalam Islam. (Munir, Ed.). Bandung: Penerbit Pustaka.

Rahmat, M. I. (2008). Ideologi Politik PKS: Dari Masjid Kampus ke Gedung Parlemen. Yogyakarta: LKis.

Rambe, S. (2008). Sarekat Islam pelopor nasionalisme Indonesia, 1905-1942. Yayasan Kebangkitan Insan Cendekia.

Rippin. (2005). Muslim: Their Religious Beliefs and Practices. London: Routledge.

Rosyad. (1995). A Quest For True Islam a Study of Islamic Resurgence Movement among The Youth in Bandung. Australy: The Australian National University Press.

Ruslan, U. (2000). Pendidikan Politik Ikhwanul Muslimin. Solo: Era Intermedia.

Said, S. (2013). Dari Gestapu ke Reformasi: Sserangkaian Kesaksian. Bandung: Mizan Pustaka.

Samsudin, Di. (2002). Etika Agama dalam Membangun Masyarakat Madani. Jakarta: Logos.

Setiawan, M. N. Kh., \& Soetapa, D. (2010). Meniti Kalam Kerukunan Beberapa Sitilah Kunci dalam Islam dan KRisten. Yogyakarta: UKDW.

Shiraishi, T. (1990). An Age in Motion: Popular Radicalism in Java, 1912-1926. Cornell University Press.

Sidiq, M. (2003). KAMMI dan Pergulatan Reformasi. Solo: Era Intermedia.

Stanley, \& Santoso, A. (2005). Soe Hok Gie: Zaman Peralihan. Jakarta: Gagas Media.

Suparman, D. (2012). Jejak Kudeta (1997-2005): Catatan Harian Jenderal (Purn.) TNI Djadja Suparman. Jakarta: Pustaka Obor.

Syaodih, N. (2009). Metode Penelitian Pendidikan. Bandung: PT. Remaja Rosdakarya.

Tibi, B. (2008). Political Islam, World Politics and Europe: Democratic Peace and Euro Islam Versus Global Jihad. London \& New York: Routledge.

Tilaar, H. A. ., \& Nugroho, R. (2008). Kebijakan Pendidikan. Yogyakarta: Pustaka Pelajar. 